\title{
The Effect of Mercury Vapor and the Role of Green Tea Extract on Brain Cells
}

\author{
Dhona Afriza \\ Department of Oral Medicine, Faculty of Dentistry, Baiturrahmah University, Padang 25176 Indonesia \\ Correspondence e-mail to:dhona_unbrah@yahoo.com
}

\begin{abstract}
Mercury is a wellknown toxic metal that is capable to induce free radical-induced oxidative stress. It can cause human disease including brain disorders. Objective: To identify the effect of mercury vapor inhalation on brain cells and the role of green tea extract (Camellia sinensis) as antioxidant on the brain cells exposed to mercury. Methods: Fourty-eight male Mus musculus were divided into 8 groups, which were given treatment for 3 and 6 weeks. Group A did not receive any treatment and served as a negative control. Group B was a positive control exposed to Mercury. Group C was exposed to Mercury and treated with $26 \mu \mathrm{g} / \mathrm{g}$ green tea extract. Group D was exposed to mercury and treated with $52 \mu \mathrm{g} / \mathrm{g}$ green tea extract. All animals in the Group B, C, D were exposed to mercury through inhalation for 4 hours daily. The effect of mercury on the brain cells were examined histopathologically. Results: The numbers of necrotic cells counted in the green tea-treated mice group were significantly lower than those untreated group $(p<0,05)$. Conclusion: Mercury vapor inhalation may cause necrosis on brain cells. Administration of green tea extract as an antioxidant reduced the amount of mercury-induced necrotic brain cells in mice.
\end{abstract}

\begin{abstract}
ABSTRAK
Pengaruh menghirup merkuri pada sel otak and efek ektrak teh hijau sebagai antioksidan. Merkuri dikenal sebagai metal yang toksik, dapat membentuk radikal bebas yang merangsang terjadinya stres oksidatif yang menyebabkan berbagai kelainan seperti kelainan otak. Tujuan: Penelitian ini bertujuan untuk mengindentifikasi pengaruh dari menghirup merkuri terhadap sel otak serta pengaruh ekstrak teh hijau (Camellia sinensis) sebagai antioksidan terhadap sel otak yang terpapar merkuri. Metode: Sampel penelitian ini adalah 48 Mus musculus jantan yang dibagi menjadi 8 grup yang diberi perlakuan selama 3 dan 6 minggu. Grup A merupakan kontrol negatif tanpa perlakuan. Grup B merupakan kontrol positif yang diberi perlakuan dengan merkuri. Grup C diberikan perlakuan dengan merkuri dan $26 \mu \mathrm{g} / \mathrm{g}$ ekstrak teh hijau. Grup D diberi perlakuan merkuri dan $52 \mu \mathrm{g} / \mathrm{g}$ ekstrak teh hijau. Seluruh mencit pada grup B, C, dan D diberikan perlakuan merkuri secara inhalasi selama 4 jam/hari. Selanjutnya dilakukan pemeriksaan histopatologi untuk mengevaluasi efek merkuri serta efek antioksidan dari ekstrak teh hijau. Hasil: Jumlah sel otak yang nekrotik lebih sedikit pada kelompok yang diberikan ekstrak teh hijau dibandingkan dengan kelompok yang tidak menerima ekstrak teh hijau. Perbedaan ini bermakna secara statistik $(p<0,05)$. Simpulan: Menghirup merkuri menyebabkan nekrosis sel otak. Pemberian ekstrak teh hijau menurunkan jumlah sel nekrotik pada mencit yang telah terpapar merkuri.
\end{abstract}

Key words: brain cells, green tea, inhaling, mercury

\section{PENDAHULUAN}

Merkuri (Hg) merupakan logam yang sangat toksik karena dapat memicu pembentukan reative oxygen species (ROS), hidrogen peroksida, lipid peroksidasi, radikal hidroksil yang semuanya merupakan radikal bebas yang dapat menyebabkan inhibisi enzim, kerusakan sel, kerusakan oksidatif DNA, kerusakan struktur protein, menghambat sintesis RNA dan DNA, menahan laju siklus sel serta mengganggu metabolisme antioksidan tubuh khususnya superoksida dismutase (SOD) dan glutation peroksidase (GPx). ${ }^{1-8}$

Merkuri (Hg) sudah lama digunakan secara luas di bidang kedokteran gigi sebagai bahan restorasi, yaitu sebagai campuran pada tambalan amalgam. ${ }^{3}$ Pasien maupun personil kesehatan gigi sangat beresiko 
terhadap keracunan merkuri, tetapi personil kesehatan gigi lebih beresiko karena mereka bisa terpapar secara terus-menerus. Merkuri dapat diabsorpsi menembus kulit atau tertelan, tetapi resiko utama dari personil kesehatan gigi adalah dari menghirup uapnya. Merkuri sangat berbahaya dalam bentuk cairan. Uap merkuri dapat terhirup atau terabsorbsi melalui alveolus di paru-paru sampai $80 \% .^{9-10}$

Sistem saraf merupakan target utama dari toksisitas metal, terutama senyawa metal organik. Misalnya metal merkuri, karena mempunyai sifat larut dalam lemak (lipid soluble), secara mudah melewati blood brain barrier dan masuk ke sistem saraf. Sebaliknya, merkuri anorganik yang lebih bersifat larut dalam air (water soluble), hanya sedikit masuk ke sistem saraf dan secara utama lebih bersifat nephrotoxicants. Merkuri yang biasa digunakan dalam tambalan amalgam termasuk golongan metal merkuri. Gejala pertama yang dirasakan pada keracunan kronik merkuri adalah rasa kesemutan, rasa baal pada kulit, jarak pandang mata menyempit, pendengaran berkurang, berjalan limbung, tremor dan daya ingat berkurang. ${ }^{10-12}$

Akibat paparan Hg yang terus menerus maka akan terjadi pembentukan radikal bebas yang akan menyebabkan penurunan aktivitas berbagai antioksidan tubuh. Penurunan aktivitas antioksidan ini akan menyebabkan terbentuknya radikal bebas yang dapat menyebabkan kerusakan membran sel, DNA, RNA, protein, termasuk kerusakan pada sel-sel otak. Maka untuk itu diperlukan antioksidan ekstraselular yang biasanya didapatkan dari makanan seperti vitamin C, vitamin E dan polifenol teh hijau.

Teh hijau mengandung polifenol yang merupakan antioksidan yang kuat. Polifenol bermanfaat untuk menangkap radikal bebas sehingga tidak mengoksidasi lemak, protein dan DNA dalam sel serta menghentikan perkembangbiakan sel-sel ganas (kanker). Flavonoid dalam polifenol adalah antioksidan yang sangat kuat yang merupakan scavenger untuk radikal anion, oksigen, peroksi radikal lipid, dan juga dapat menghilangkan daya reaktif ion metal melalui penempelan. ${ }^{13-16}$

Sebagian besar bukti eksperimental menunjukkan aktivitas neuroprotektif antioksidan telah dipelajari secara in vitro dalam jaringan dan sel. Karena sensitivitas sel-sel sistem saraf pusat (SSP) yang tinggi terhadap kerusakan oksidatif, pemasukan antioksidan penting untuk optimalisasi kelangsungan hidup sel serta menjaga kelangsungan hidup jangka panjang saraf dan pencegahan neurodegeneratif. ${ }^{17}$

Pada penelitian pendahuluan yang dilakukan pada tahun 2008, terdapat perbedaan kadar merkuri dalam darah yang signifikan antara mencit terpapar merkuri pada kelompok yang diberi ekstrak teh hijau dengan mencit tidak terpapar merkuri yang tidak diberi ekstrak teh hijau pada dosis $0,52 \mathrm{mg}$ dan $0,78 \mathrm{mg} / 20 \mathrm{~g}$ berat badan. Pada mencit yang diberi ekstrak teh hijau terdapat kadar merkuri dalam darah yang lebih rendah dibandingkan dengan kelompok yang tidak diberi ekstrak teh hijau. ${ }^{18}$ Dari latar belakang yang telah diuraikan, peneliti ingin mengetahui bagaimana pengaruh merkuri secara inhalasi terhadap sel-sel otak secara histopatologis dan apakah ada pengaruh ekstrak teh hijau terhadap sel-sel otak mencit yang terpapar merkuri.

\section{METODE}

Penelitian ini merupakan penelitian eksperimental murni yang dilakukan pada mencit putih (Mus musculus) jantan, yang terdapat di Laboratorium Farmasi Universitas Andalas. Sampel sebanyak 48 ekor mencit putih jantan tersebut dibagi ke dalam 8 kelompok secara acak sederhana. Teh hijau yang digunakan adalah teh hijau yang ada di pasaran dengan merk Teh Hijau (Green Tea) cap Kepala Djenggot, yang diekstraksi di Laboratorium Kesehatan Propinsi Sumatera Barat. Merkuri yang digunakan adalah jenis merkuri metal yang biasa digunakan sebagai bahan tambal amalgam. Sel-sel otak dilihat secara histopatologis. Preparat histopatologis dibuat dengan pewarnaan HE (Hematoksilin Eosin), dinilai dengan mikroskop cahaya binokuler pada pembesaran 400× (40x objektif), diperiksa di Laboratorium Patologi Anatomi Fakultas Kedokteran UNAND. Penelitian ini dilakukan selama bulan Februari - Juni 2011.

Pada penelitian ini digunakan mencit putih (Mus musculus) dengan berat badan 20-25g, dipilih secara acak sederhana. Mencit yang digunakan sebanyak 48 ekor, yang dibagi ke dalam 8 kelompok secara acak yaitu kelompok A, B, C, dan D (dengan perlakuan 3 dan 6 minggu). Masing-masing kelompok terdiri dari 6 ekor mencit. Kelompok A adalah kelompok kontrol negatif yang tidak diberikan perlakuan, Kelompok B adalah kelompok kontrol positif yang hanya dipapar dengan merkuri saja tanpa pemberian ekstrak teh hijau. Kelompok $\mathrm{C}$ adalah kelompok yang dipapar dengan merkuri dan diberi ekstrak teh hijau dengan dosis $0,52 \mathrm{mg} / 20 \mathrm{~g}$. Kelompok D adalah kelompok perlakuan yang dipapar dengan merkuri dan diberi ekstrak teh hijau dengan dosis $1,04 \mathrm{mg} / 20 \mathrm{~g}$.

Mencit pada kelompok B, C dan D dipapar dengan merkuri secara inhalasi selama 4 jam sehari. Mencit diletakkan dalam kandang dengan desain khusus, diberikan perlakuan dan pakan yang sama. Pada minggu ketiga dan keenam, sel-sel otak masingmasing kelompok diperiksa dengan membuat preparat histopatologis di Laboratorium Patologi Anatomi Fakultas Kedokteran Universitas Andalas. Preparat tersebut diperiksa dengan mikroskop cahaya binokuler 
Tabel 1. Perbedaan rerata jumlah sel hidup pada otak mencit pada bermacam-macam dosis dan lama pemberian ekstrak teh hijau

\begin{tabular}{|c|c|c|c|c|c|}
\hline \multirow{2}{*}{$\begin{array}{c}\text { Lama } \\
\text { pemberian } \\
(\text { minggu })\end{array}$} & \multicolumn{4}{|c|}{ Jumlah sel hidup } & \multirow{2}{*}{$p$} \\
\hline & $\mathbf{A}$ & B & $\mathrm{C}$ & D & \\
\hline 3 & $297,5 \pm 15,0$ & $165,0 \pm 10,0$ & $245,00 \pm 5,8$ & $242,50 \pm 5.0$ & $* 0,004$ \\
\hline 6 & $297,5 \pm 15,0$ & $95,0 \pm 5,8$ & $145,00 \pm 10,0$ & $155,00 \pm 5,8$ & $* 0,004$ \\
\hline$p$ & 1,000 & $* 0,000$ & $* 0,000$ & $* 0,000$ & \\
\hline
\end{tabular}

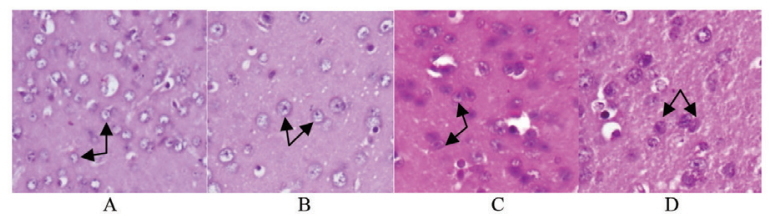

Gambar 1. Gambaran histopatologis sel-sel otak mencit putih sesuai kelompok perlakuan selama 3 minggu: Kelompok A (kontrol): Jumlah sel neuron kurang lebih 297 per lapang pandang besar; Kelompok B 3 minggu (Hg): Jumlah sel neuron kurang lebih 165 per lapang pandang besar, Kelompok C 3 minggu ( $\mathrm{Hg}+26 \mu \mathrm{g} / \mathrm{g}$ ekstrak teh hijau): Jumlah sel neuron kurang lebih 245 per lapang pandang besar; Kelompok D 3 minggu ( $\mathrm{Hg}+52 \mu \mathrm{g} / \mathrm{g}$ ekstrak teh hijau): Jumlah sel neuron kurang lebih 242 per lapang pandang besar.

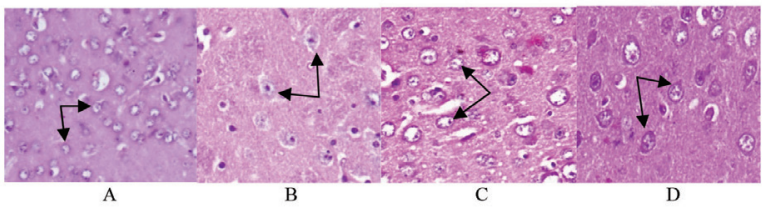

Gambar 2. Gambaran histopatologis sel-sel otak mencit putih sesuai kelompok perlakuan selama 6 minggu: Kelompok A (kontrol): Jumlah sel neuron kurang lebih 297 per lapang pandang besar; Kelompok B 6 minggu (Hg): Jumlah sel neuron kurang lebih 95 per lapang pandang besar; Kelompok C 6 minggu $(\mathrm{Hg}+26 \mu \mathrm{g} / \mathrm{g}$ ekstrak teh hijau): Jumlah sel neuron kurang lebih 145 per lapang pandang besar; Kelompok D 6 minggu $(\mathrm{Hg}+52 \mu \mathrm{g} / \mathrm{g}$ ekstrak teh hijau): Jumlah sel neuron kurang lebih 155 per lapang pandang besar.

untuk melihat kerusakan yang terjadi pada sel-sel otak. Data yang diperoleh diolah dan dianalisis dengan menggunakan Uji Mann-Whitney dan uji t independen dengan Interval Kepercayaan 95\%.

\section{HASIL}

Pada Tabel 1 terlihat jumlah sel hidup pada kelompok perlakuan tiga minggu, terjadi penurunan jumlah sel hidup sangat banyak pada kelompok B (yang dipaparkan merkuri tanpa pemberian ekstrak teh hijau) dibandingkan dengan kelompok kontrol (A). Pada kelompok C dan D (yang diberi $26 \mu \mathrm{g} / \mathrm{g}$ BB dan $52 \mu \mathrm{g} / \mathrm{g}$ BB) terdapat penurunan jumlah sel hidup sangat sedikit dibanding kelompok kontrol. Terdapat perbedaan yang signifikan pada keempat kelompok. Pada perlakuan enam minggu terlihat perbedaan yang signifikan pada keempat kelompok pada kelompok B terjadi penurunan jumlah sel-sel hidup yang paling banyak diantara kelompok yang lain.

Perbandingan diantara berbagai kelompok 3 minggu perlakuan: perbandingan jumlah sel hidup pada kelompok kontrol (A) dengan kelompok B menunjukkan hasil yang signifikan $(\alpha=0,017)$, demikian juga perbandingan antara kelompok $\mathrm{A}$ dengan $\mathrm{C}$ dan kelompok A dengan D. Pada kelompok B dengan $\mathrm{C}$ dan $\mathrm{B}$ dengan $\mathrm{D}$ juga memperoleh hasil yang signifikan (Gambar 1). Perbandingan jumlah sel hidup pada berbagai kelompok selama perlakuan 6 minggu perbandingan jumlah sel hidup pada kelompok A dan B menunjukkan hasil yang signifikan, demikian juga pada kelompok yang lain, kecuali perbandingan antara kelompok C dan D (Gambar 2).

\section{PEMBAHASAN}

Hasil penelitian menunjukkan terjadi penurunan jumlah sel-sel hidup pada otak secara signifikan setelah dipaparkan pada merkuri secara inhalasi selama tiga dan enam minggu (Tabel 1). Pada kelompok yang dipaparkan pada merkuri saja tanpa pemberian ekstrak teh hijau selama tiga minggu jumlah sel-sel hidup berkurang sangat signifikan.

Paparan merkuri yang lebih lama akan menyebabkan jumlah sel-sel hidup juga akan berkurang. Hal ini terlihat pada perlakuan tiga minggu dan enam minggu, jumlah sel hidup semakin berkurang pada paparan merkuri selama enam minggu. Nekrosis sel yang terjadi sangat besar. Pada pemeriksaan histopatologis otak yang dapat diamati hanya sel-sel yang hidup, karena proses kematin sel yang terjadi berlangsung sangat cepat, sehingga sel-sel yang sedang berdegenerasi atau yang sedang mengalami proses kematian tidak dapat diamati.

Paparan merkuri dapat menghasilkan efek yang sangat bervariasi. Semua bentuk efek merkuri tergantung pada besarnya dan lamanya terpapar dan juga umur dan status kesehatan individu yang paparan. Terpapar pada metal merkuri pada kadar yang signifikan dapat menghasilkan efek pada sistem saraf, pernafasan, ginjal, sistem imun, kehamilan, dermatologi dan bermacam-macam efek yang lain. ${ }^{1,12}$ Sistem saraf merupakan target utama dari toksisitas metal, terutama senyawa metal organik. Metal merkuri karena bersifat larut lemak, secara mudah melewati blood brain barier dan masuk ke dalam sistem saraf. ${ }^{11,12}$ 
Merkuri diketahui merupakan metal yang toksik yang menyebabkan stres oksidatif di jaringan. Konsentrasi submikromolar dari $\mathrm{HgCl}_{2}$ atau metilmerkuri memicu produksi ROS. ${ }^{5}$ Merkuri dapat masuk ke dalam sel dan merusak sel. Merkuri dapat mengurangi produksi glutation (GSH) dan menghambat aktivitas enzim glutation peroksidase (GPx) dan menimbulkan stres oksidatif pada otak dan organ tubuh lainnya. ${ }^{3,19}$ Bukti menunjukkan bahwa akumulasi oksidasi DNA, protein dan lipid oleh radikal bebas bertanggung jawab atas penurunan fungsional otak. Juga produk dari peroksidasi lipid seperti MDA, HNE dan aksolem dilaporkan bereaksi dengan DNA dan protein untuk menghasilkan kerusakan lebih lanjut dalam otak. Radikal bebas sangat berperan dalam kerusakan sel di otak dan antioksidan endogen maupun eksogen efektif dalam terapi terkait gangguan neurodegenerative. ${ }^{20}$

Pada penelitian ini terlihat sebagian besar sel-sel otak mengalami nekrosis akibat paparan merkuri. Tipe nekrosis yang terjadi pada sel-sel otak adalah liquefactiva, yaitu jaringan berubah menjadi cairan dengan cepat, dengan tanda radang yang minimal. Oleh karena itu, pada penelitian ini, sel-sel yang sedang mengalami kerusakan, tidak terlihat dengan jelas karena sel-selnya mengalami nekrosis dan menghilang dengan cepat. Tipe nekrosis pada jaringan lain adalah nekrosis koagulativa, yakni jaringan memadat dengan tanda radang yang jelas dan proses kematian sel berlangsung lebih lama. ${ }^{21}$

Otak mengandung konsentrasi asam lemak tak jenuh yang lebih tinggi dibandingkan dengan jaringan lain. Peroksida lipid merupakan hasil utama dari radikal bebas yang menyebabkan cedera pada jaringan otak. ${ }^{17}$ Otak lebih rentan terhadap stress oksidatif karena kandungan dari asam lemak tak jenuh, konsumsi per satuan berat, tingginya kandungan bahan utama peroksidasi lipid (besi dan askorbat) dan minimnya sistem pertahanan antioksidan. ${ }^{20}$ Sekali membran sel terganggu, pemulihan sel-sel otak tidak mungkin terjadi. Radikal bebas sangat toksik bagi sel. Pembentukan radikal bebas dan protease akan mengganggu membran sel otak dan akan menyebabkan kerusakan yang ireversibel. ${ }^{22}$

ROS (reative oxygen species) dan RNS (reative nitrogen species) mampu memodifikasi protein, lipid dan asam nukleat. Organisme hidup mempunyai beberapa mekanisme untuk melindungi diri dari serangan ROS dan RNS yaitu dengan scavenging ROS / RNS dan prekursornya, mengikat ion logam katalitik yang diperlukan untuk pembentukan ROS serta menghasilkan dan mengatur system pertahanan antioksidan endogen. Radikal bebas bereaksi sangat cepat, kerusakan oksidatif ROS sebagian besar pada mitokondria dangan DNA menjadi target utama. Dalam otak konsentrasi asam lemak jenuh dan oksida nitrat yang tinggi akan meningkatkan resiko kerusakan oksidatif bahkan kematian saraf. ${ }^{23}$
Jumlah sel-sel hidup berbeda secara signifikan antara kelompok yang diberi ekstrak teh hijau dengan yang tidak diberi ekstrak teh hijau, jumlah sel hidup jauh lebih banyak pada kelompok yang diberi teh hijau dibandingkan dengan kelompok yang tidak diberi ekstrak teh hijau (B). Artinya jumlah sel yang nekrosis jauh lebih sedikit pada kelompok yang diberi ekstrak teh hijau (kelompok $\mathrm{C}$ dan D) dibandingkan dengan kelompok yang tidak diberi ekstrak teh hijau (B). Hal ini terjadi pada perlakuan tiga minggu maupun enam minggu.

Antioksidan yang dapat mencegah kerusakan akibat radikal bebas dipertimbangkan sebagai pendekatan yang menjanjikan sebagai neuroprotektif. Sebagian besar bukti eksperime, telah menunjukkan aktivitas neuroprotektif antioksidan secara in vitro pada jaringan/ kultur sel. Antioksidan alami seperti melatonin, flavonoid dan polifenol dapat mengurangi kerusakan oksidatif sel-sel saraf karena mempunyai kemampuan sebagai scavenger pada banyak radikal bebas. ${ }^{17,25}$

Polifenol mempunyai reaktivitas yang tinggi terhadap ROS dan mengurangi peroksida. Polifenol juga telah menunjukkan untuk menekan peroksida lipid dan kerusakan DNA, lebih jauh polifenol juga bisa memproteksi dalam melawan berbagai macam penyakit yang berhubungan dengan ROS, misalnya gangguan kardiovaskular pada manusia, ischemia reperfusion injuries pada hati kelinci dan aterosklerosis pada tikus. $^{15,24}$

Epigallocatechin gallate (EGCG) mempunyai efek neuroprotektif terhadap cedera saraf dan dapat mengurangi 6-hydroxydopamine yang menyebabkan apoptosis pada sel PC12. Sudah dibuktikan bahwa mekanisme disregulasi ROS berhubungan dengan berbagai penyakit dan polifenol mempunyai aktivitas antioksidan yang sangat kuat secara in vitro dan juga sebagai scavenger berbagai ROS dan RNS. ${ }^{25}$

Percobaan pada polifenol teh hijau dapat menghambat lipid peroksida. EGCG dapat memberikan perlindungan kerusakan oksidatif dari DNA, dengan menembus scavenging langsung dari ROS. Penelitian ini juga telah memperlihatkan bahwa konsentrasi rendah polifenol teh hijau dapat mengurangi radikal hidroksil penyebab kerusakan dasar dan kerusakan DNA single strand, oleh mekanisme transfer elektron dari katekin ke sisi radikal pada DNA. Secara in vivo, polifenol teh hijau juga menghambat UVB penyebab petanda stres oksidatif pada binatang sebelum perlindungan radiasi UVB melawan deplesi glutation, enzim antioksidan glutation peroxidase dan katalase, mengurangi UV penyebab lipid peroksidasi dan menghambat UVB penyebab oksidasi protein. EGCG melindungi perlawanan UVpenyebab stress oksidatif pada manusia secara baik. ${ }^{24}$ Sejumlah studi menjelaskan bahwa polifenol dan katekin teh merupakan scavenger efektif secara fi- 
siologis berkaitan dengan oksigen reaktif dan spesies nitrogen secara in vivo, meliputi superoksida $\left(\mathrm{O}_{2}{ }^{\circ-}\right)$, radikal peroksil, oksigen singlet, peroksi nitrit ( $\left.\mathrm{ONOO}^{-}\right)$ dan asam hipoklorit. ${ }^{13}$ Glutation (GSH) merupakan antioksidan intra selular yang penting dan dalam kondisi fisiologis kemampuan scavenging yang radikal adalah mekanisme utama untuk menghilangkan ROS yang berlebihan. Perubahan dalam metabolisme GSH dapat dicapai melalui pemberian polifenol khususnya EGCG. Efek jangka panjang pada metabolism GSH secara signifikan terjadi penambahan kadar total GSH setelah 24 jam pemaparan ke EGCG, methyl gallate dan gallic acid tanpa adanya stres. ${ }^{25}$

Kadar katekin dalam plasma manusia telah terbukti mencapai puncaknya dalam waktu 2 sampai 4 jam setelah mengkonsumsi teh hijau. Ekstrak teh hijau dan campuran tanin telah terbukti sebagai scavenger oksida nitrat (NO) dan superoksida. Katekin teh hijau telah terbukti memperpanjang waktu jeda (lag), menghambat pembentukan kolesterol teroksidasi dan menurunkan konsentrasi asam linoleat dan asam arakidonat. Katekin teh hijau juga dapat mengurangi oksidasi LDL, pembentukan substansi reaktif asam tiobarbiturat, oksidasi selular dan produksi superoksida. ${ }^{26}$

Mengkonsumsi makanan dan minuman yang kaya akan polifenol dapat meningkatkan kadar antoksidan secara in vivo. ${ }^{27}$ Pengujian yang dilakukan pada lima katekin: epigallocatechin-3-gallate (EGCG), epigallocatechin (EGC), epicatechin-3-gallate (ECG), dan epicatechin (EC) dan katekin (C) sehubungan dengan efeknya pada 6-OHDA penyebab apoptosis oksidatif dalam sel PC12 menunjukkan perbedaan yang signifikan dalam tingkat perlindungan antioksidan oleh antioksidan fenolik tersebut. Data menunjukkan bahwa dua dari lima senyawa tersebut yaitu EGCG dan ECG, berpotensi sebagai neuroprotektif terhadap penyakit Parkinson. ${ }^{17,28}$

Antioksidan yang ditemukan dalam teh hijau dan tanaman lainnya dapat melawan kerusakan oksidatif dalam beberapa cara. EGCG dan antioksidan lain dapat mentralisir radikal bebas dalam tubuh, scavenger ROS dan RNS yang berbahaya sebelum menyebabkan kerusakan oksidatif pada komponen sel. Antioksidan ini memiliki afinitas yang tinggi untuk beberapa ion logam, dapat bertindak sebagai chelator logam, menonaktifkan transisi redoks aktif ion logam yang akan mengkatalisis pembentukan radikal bebas. EGCG dapat mencegah kerusakan oksidatif seluler dengan menghambat enzim-enzim lipoksigenase, siklooksigenase dan xantin oksidase, yang semuanya berpotensi menyebabkan kerusakan oksidatif pada beberapa jaringan oleh aktivitas peroksidase mereka. ${ }^{29}$ EGCG dapat menghambat lipid peroksida dan memberi perlindungan kerusakan oksidatif DNA. ${ }^{24}$

Telah dilaporkan bahwa EGCG yang merupakan komponen utama polifenol mempunyai aktivitas modulasi fisiologi yang bervariasi seperti efek antibakteri, aksi scavenging radikal, mencegah arterosklerosis dan aktivitas antioksidan. ${ }^{30}$ Penelitian sebelumnya menunjukkan bahwa EGCG mempunyai efek neuroprotektif terhadap edema neuronal dan mengurangi 6-hydroxydopamine dopamine yang menyebabkan apoptosis pada sel PC12. Selanjutnya beberapa laporan menunjukkan bahwa pretreatment dengan EGCG melemahkan peningkatan rasio Bax ke Bcl-2, yang merupakan penanda apoptosis yang meningkat karena stres oksidatif pada sel-sel PC12. ${ }^{25}$

Produksi yang terus menerus dalam jumlah yang besar dari ROS dan RNS dapat menyebabkan perubahan transduksi sinyal dan ekspresi gen, sehingga menyebabkan perkembangan penyakit. Kerusakan selular dapat diperantarai oleh $\mathrm{ROS}\left(\mathrm{H}_{2} \mathrm{O}_{2}\right.$, radikal hidroksil, anion superoksida). Oksida nitrat (NO) dapat menyebabkan apoptosis pada sel-sel saraf dan terlibat dalam iskemia otak, neurodegenerasi, inflamasi dan vasorelaksasi. Banyak polifenol mempunyai kemampuan secara signifikan mengubah kadar NO dalam kondisi stres maupun non stres. ${ }^{25}$

Untuk mencegah efek berbahaya dari ROS, sel memerlukan banyak mekanisme pertahanan diri enzimatik dan nonenzimatik endogen melawan stress oksidatif. Katalase, superoksida dismutase (SOD) dan Glutation peroksidase (GPx) merupakan mekanisme pertahanan enzimatis, sementara askorbat, asam urat dan glutation (GSH) termasuk mekanisme nonenzimatis. ${ }^{25}$

Polifenol teh menghambat pembentukan ROS dengan menghambat enzim xanthine oxidase. Xantine oxidase mengkatalisis oksidasi hipoxantine dan xantine ke asam urat, ketika pengurangan $\mathrm{O}_{2}$ ke $\mathrm{O}_{2}{ }^{\circ-}$ dan $\mathrm{H}_{2} \mathrm{O}_{2}$. Katekin teh hijau dapat menghambat aktivitas xantine oxidase secara in vitro, dengan EGCG menggunakan efek paling poten. Pada kultur sel leukemia manusia, EGCG dari teh hijau dan theaflavin gallates dari teh hitam juga menghambat aktivitas xantine oxidase. ${ }^{13}$

Percobaan pada polifenol teh hijau dapat menghambat lipid peroksida. EGCG dapat memberikan perlindungan kerusakan oksidatif dari DNA, dengan menembus scavenging langsung dari ROS. Penelitian ini juga telah memperlihatkan bahwa konsentrasi rendah polifenol teh hijau dapat mengurangi radikal hidroksilpenyebab kerusakan dasar dan kerusakan DNA single strand, oleh mekanisme transfer elektron dari katekin ke sisi radikal pada DNA. Secara in vivo, polifenol teh hijau juga menghambat UVB penyebab petanda stress oksidatif pada binatang sebelum perlindungan radiasi UVB melawan deplesi glutation, enzim antioksidan glutathione peroxidase dan katalase, mengurangi UV penyebab lipid peroksidasi dan menghambat UVB penyebab oksidasi protein. EGCG melindungi perlawanan UV penyebab stress oksidatif pada manusia secara baik. ${ }^{24}$ 
Jadi dengan berkurangnya merkuri akibat fungsi dari polifenol teh hijau yang dapat mengikat ion logam, sebagai scavenger radikal bebas serta dapat meningkatkan aktivitas enzim-enzim antioksidan (GPX, SOD dan katalase) dalam tubuh, maka ekstrak teh hijau secara tidak langsung dapat mengurangi kerusakan sel-sel tubuh akibat radikal bebas yang ditimbulkan oleh merkuri, termasuk sel-sel otak.

\section{SIMPULAN}

Dari hasil penelitian dapat diambil kesimpulan bahwa merkuri secara inhalasi berpengaruh terhadap nekrosis sel-sel otak secara histopatologis dan pemberian ekstrak teh hijau sebagai antioksidan berpengaruh terhadap jumlah nekrosis yang terjadi pada sel-sel otak mencit yang terpapar merkuri.

\section{DAFTAR PUSTAKA}

1. Scientific Committee on Emerging and Newly Identified Health Risk (SCENIHR). Safety of dental amalgam and alternative dental restoration materials. [Internet]. 2008. [cited 2012 Mei 12]. Available from: http://ec.europa.eu/health/ph_risk/ risk_en.htm.

2. Rizvi SJ, Zahir F, Jairajpuri S. Mercury: the lurking danger. Anil Aggrawal's Internet Journal of Forensic Medicine and Toxicology: 6(1). [Internet]. 2005. [cited 2012 april 13]. Available from: http:// www.indianjournals.com/ijor.aspx?target=ijor:aaij fmt $\&$ volume $=6 \&$ issue $=1 \&$ article $=005$.

3. Cline JC. Mercury toxicity and the use of DMPS chelation [Internet]. 2005. [cited 2011 April 20]. Available from:http://www.talkinternational.org/.

4. Larsen HR. Amalgam (silver) fillings. summaries of the latest research concerning amalgam fillings. [Internet]. 2005. [cited 2011 April 20]. Available from: http://www.yourhealthbase.com/amalgam. htm.

5. Chen YW, Huang CF, Tsai KS, Yang RS, Yen CC, Yang CY, Lin-Shiau SY, Liu SH. The role of phosphoinositide 3-kinase/Akt signaling in low-dose mercury-induced mouse pancreatic betacell dysfunction in vitro and in vivo. Diabetes. 2006;55:1614-24.

6. Singh R. Your dental practice could be killing you and your family. [Internet]. 2007. [cited 2011 April 20]. Available from: http://www.noharm.org/ details.cfm?ID=1201\&type=document.

7. Pleva J. Mercury from dental amalgams: exposure and effects. Int J Risk Saf Med. 1992;3:1-22.

8. Maloney DW. How I was cured of mercury amalgam poisoning. Drug Topics. 2007;151: 56-7.

9. Trzcinka-Ochocka M, Gazewski A, Brodzka R. Exposure to mercury vapors in dental workers in Poland. Int J Occup Med Environ Health.
2007;20:147-53.

10. Inswiasri. Paradigma kejadian penyakit pajanan merkuri (Hg). Jurnal Ekologi Kesehatan. Agustus 2008; 7(2);775-785. Indonesian.

11. Cope WG, Leidy RB, Hodgson E. Classes of toxicants: uses classes. In: A textbook of modern toxicology. Hodgson E, editors. 3rd ed. USA: Wiley-Intersience; 2004. p. 49-54.

12. Risher JF, Rosa CTD. Inorganic: the other mercury. J Environ Health. 2007;70:9-17.

13. Frei B, Higdon JV. Antioxidant activity of tea polyphenols in vivo: evience from animals studies. J Nutr. 2003;133:3275s.

14. Payne D. Polifenol-rich juice offers protection againts Alzheimer's. Medical Post. 2006;42:27-8.

15. Abe S, Tanaka Y, Fujise N, Nakamura T, Masunaga H, Nagasawa T, Yagi M. An antioxidative nutrientrich enteral diet attenuates lethal activity and oxidative stress induced by lipopolysaccharide in mice. JPEN J Parenter Enteral Nutr. 2007;31:181-7.

16. Hsu SP, Wu MS, Yang CC, Huang KC, Liou SY, Hsu SM, Chien CT. Chronic green tea extract supplementation reduces hemodialysis-enhanced production of hydrogen peroxide and hypochlorous acid, atherosclerotic factors, and proinflammatory cytokines. Am J Clin Nutr. 2007;86:1539-47.

17. Aksenova MV, Aksenov MY, Mactutus CF, Booze RM. Cell culture models of oxidative stress and injury in the central nervous system. Curr Neurovasc Res. 2005;2:73-89.

18. Afriza D, Widiawati. Influence of green tea extract to reduce mercury level in blood. Proceeding of Asian Oral Health Care Conference; 2008. Jakarta Indonesia. 2008.

19. Kobal AB, Horvat M, Prezelj M, Briski AS, Krsnik M, Dizdarevic T, Mazej D, Falnoga I, Stibilj V, Arneric N, Kobal D, Osredkar J. The impact of longterm past exposure to elemental mercury on antioxidative capacity and lipid peroxidation in mercury miners. J Trace Elem Med Biol. 2004;17:261-74.

20. Poon HF, Calabrese V, Scapagnini G, Butterfield DA. Free radicals and brain aging. Clin Geriatr Med. 2004 May;20:329-59.

21. Kumar, Abbas, Fausto, editors. Robin \& CotranPathologic Basis of Diseases. 7th ed. Philadelphia: Elsevier 2005.

22. Jha SK. Cerebral edema and its management. MJAFI 2003;59:326-31.

23. Storm T, Rath S, Mohamed SA, Bruse P, Kowald A, Oehmichen M, Meissner C. Mitotic brain cells are just as prone to mitochondrial deletions as neurons: a large-scale single-cell PCR study of the human caudate nucleus. Exp Gerontol. 2002:37: 1387-98.

24. Yusuf N, Irby C, Katiyar SK, Elmets CA. Photoprotective effects of green tea polyphenols. Photodermatol Photoimmunol Photomed. 2007;23:48-56.

25. Crispo JA, Ansell DR, Piche M, Eibl JK, Khaper N, Ross GM, Tai TC. Protective effects of polyphenolic compounds on oxidative stress-induced cytotoxicity in PC12 cells. Can J Physiol Pharma- 
col. 2010;88:429-38.

26. Basu A, Lucas EA. Mechanisms and effects of green tea on cardiovascular health. Nutr Rev. 2007;65:361-75.

27. Pan T, Jankovic J, Le W. Potential therapeutic properties of green tea polyphenols in Parkinson's disease. Drugs Aging. 2003;20:711-21.

28. Jin CF, Shen SR Sr, Zhao BL. Different effects of five catechins on 6-hydroxydopamine-induced apoptosis in PC12 cells. J Agric Food Chem. 2001;49:6033-8.
29. Carlson JR, Bauer BA, Vincent A, Limburg PJ, Wilson T. Reading the tea leaves: anticarcinogenic properties of (-)-epigallocatechin-3-gallate. Mayo Clin Proc. 2007;82:725-32.

30. Kawai K, Tsuno NH, Kitayama J, Okaji Y, Yazawa K, Asakage M, Hori N, Watanabe T, Takahashi $\mathrm{K}$, Nagawa H. Epigallocatechin gallate, the main component of tea polyphenol, binds to CD4 and interferes with gp120 binding. J Allergy Clin I munol. 2003;112:951-7. 